\title{
Origin of dolomite in the Middle Ordovician peritidal platform carbonates in the northern Ordos Basin, western China
}

\author{
Xiao-Liang Bai ${ }^{1,2} \cdot$ Shao-Nan Zhang ${ }^{1,2}$ - Qing-Yu Huang ${ }^{3}$ Xiao-Qi Ding ${ }^{4}$. \\ Si-Yang Zhang ${ }^{5}$
}

Received: 17 September 2015/Published online: 10 August 2016

(c) The Author(s) 2016. This article is published with open access at Springerlink.com

\begin{abstract}
The carbonates in the Middle Ordovician $\mathrm{Ma}_{5}^{5}$ submember of the Majiagou Formation in the northern Ordos Basin are partially to completely dolomitized. Two types of replacive dolomite are distinguished: (1) type 1 dolomite, which is primarily characterized by microcrystalline $(<30 \mu \mathrm{m})$, euhedral to subhedral dolomite crystals, and is generally laminated and associated with gypsumbearing microcrystalline dolomite, and (2) type 2 dolomite, which is composed primarily of finely crystalline $(30-100 \mu \mathrm{m})$, regular crystal plane, euhedral to subhedral dolomite. The type 2 dolomite crystals are truncated by stylolites, indicating that the type 2 dolomite most likely predated or developed simultaneously with the formation of the stylolites. Stratigraphic, petrographic, and geochemical data indicate that the type 1 dolomite formed from near-surface, low-temperature, and slightly evaporated seawater and that the dolomitizing fluids may have been driven by density differences and elevation-related hydraulic head. The absence of massive depositional
\end{abstract}

Shao-Nan Zhang

zsn@cdut.edu.cn

1 State Key Laboratory of Oil and Gas Reservoir Geology and Exploitation, Southwest Petroleum University, Chengdu 610500, Sichuan, China

2 School of Geoscience and Technology, Southwest Petroleum University, Chengdu 610500, Sichuan, China

3 Research Institute of Petroleum Exploration \& Development, PetroChina, Beijing 100083, China

4 College of Energy, Chengdu University of Technology, Chengdu 610059, Sichuan, China

5 Department of Geology, University of Regina, Regina, SK S4S 0A2, Canada

Edited by Jie Hao evaporites in the dolomitized intervals indicates that dolomitization was driven by the reflux of slightly evaporated seawater. The $\delta^{18} \mathrm{O}$ values $(-7.5$ to $-6.1 \%$ ) of type 1 dolomite are slightly lower than those of seawaterderived dolomite, suggesting that the dolomite may be related to the recrystallization of dolomite at higher temperatures during burial. The type 2 dolomite has lower $\delta^{18} \mathrm{O}$ values $\left(-8.5\right.$ to $-6.7 \%$ ) and $\mathrm{Sr}^{2+}$ concentration and slightly higher $\mathrm{Na}^{+}, \mathrm{Fe}^{2+}$, and $\mathrm{Mn}^{2+}$ concentrations and ${ }^{87} \mathrm{Sr} /{ }^{86} \mathrm{Sr}$ ratios $(0.709188-0.709485)$ than type 1 dolomite, suggesting that the type 2 dolomite precipitated from modified seawater and dolomitic fluids in pore water and that it developed at slightly higher temperatures as a result of shallow burial.

Keywords Carbonate platform - Dolomitization . Dolomite $\cdot$ Middle Ordovician $\cdot \mathrm{Ma}_{5}^{5}$ submember . Dolomitizing fluids

\section{Introduction}

The origin of dolomitization has long been a subject of discussion (Warren 2000; Machel 2004; Gregg et al. 2015). Various models have been proposed to explain the origin of dolomite in carbonate platforms (Warren 2000; Machel 2004; Swart 2015), including regional subsurface flow models (sometimes referred to as burial-flow models) at elevated temperatures (Jones and Rostron 2000) and "early" synsedimentary models, such as those involving seepage reflux (Adams and Rhodes 1960). These models have been used to explain the massive dolomite in syndepositional evaporites (Jones and Rostron 2000; Qing et al. 2001) or in seawater with elevated salinity (Rott and Qing 2013; Read et al. 2012; Rivers et al. 2012). However, the 
development of small-scale, discrete dolomites in platform carbonates in association with elevated salinity seawater and little gypsum is less well documented. This study focuses on the early, pervasive dolomitization of shallow marine platform carbonates by penesaline seawater related to sea-level changes and the subsequent recrystallization of this early-formed dolomite during burial. This study then interprets the discrete, regional-scale distribution of dolomite that may have originated from modified seawater with high-frequency sequence cyclic changes and the precipitation of dolomitic fluids during burial.

The carbonates in the Middle Ordovician $\mathrm{Ma}_{5}^{5}$ submember of the Majiagou Formation in the northern Ordos Basin are partially to completely dolomitized and are an attractive target for hydrocarbon exploration. In particular, the discovery of gas reservoirs in the dolomitic strata in the Jingbian Gas Field was an important finding involving the $\mathrm{Ma}_{5}^{5}$ submember, which displays good natural gas exploration prospects among the old dolomite strata of the Ordos Basin. Tests in well Su-203 resulted in a large gas flow rate of over $104 \times 10^{4} \mathrm{~m}^{3} / \mathrm{d}$ from the dolomite reservoirs (Yang and Bao 2011; Zhao et al. 2014), and horizontal well PG3 had a gas flow rate of over $10 \times 10^{4} \mathrm{~m}^{3} / \mathrm{d}$ from the dolomite reservoir of the $\mathrm{Ma}_{5}^{5}$ submember. Since then, exploration and development of the dolomite gas pools in the $\mathrm{Ma}_{5}^{5}$ submember have been the key goal.

The dolomite in the $\mathrm{Ma}_{5}^{5}$ submember is characterized by an uneven and discontinuous distribution of dolomitic carbonates and is classified as a low-seepage lithologic reservoir (Yang et al. 2006; Fang et al. 2009; Zhao et al. 2014), which is attributed to depositional facies and diagenetic alteration. Dolomitization can greatly influence porosity and permeability as limestone is replaced (Warren 2000; Zhang et al. 2010); however, the heterogeneity of the rock is closely related to the distribution and origin of the dolomite. Previous studies of the $\mathrm{Ma}_{5}^{5}$ submember in the study area focused on its depositional environments and stratigraphic distribution (Wang et al. 2014). Additionally, many scholars have studied the origin of dolomite in the $\mathrm{Ma}_{5}$ member in the Ordos Basin, and various models of its diagenesis have been proposed, including those involving mixed water zones and dolomitization (Zhao et al. 2005), evaporative reflux (Liu et al. 2011; He et al. 2014), burial dolomitization (Wang et al. 2009; Huang et al. 2010; Su et al. 2011), hydrothermal dolomitization (Huang et al. 2010; Wang et al. 2015), and microbial dolomitization (Fu et al. 2011). However, most of these studies have not provided an integrated stratigraphic, petrographic, or geochemical framework. This study focuses on the dolomitization of the carbonate deposits in the $\mathrm{Ma}_{5}^{5}$ submember using petrography, stratigraphy, and geochemistry, and assesses the implications for hydrocarbon resource exploration.

\section{Geologic setting}

The Ordos Basin is a large-scale, multicycle, stable craton in northwestern China. The basement of the Ordos platform is composed of Precambrian crystalline schist, gneiss, and marble. In the Paleozoic Era, the Ordos Basin experienced steady uplift and subsidence with weak tectonic activity in the interior of the platform. During this period, particularly during the Ordovician, the depositional paleogeomorphology was generally higher in the north and middle and lower in the east, west, and south, and the Ordos Basin developed a gently inclined carbonate platform in a very shallow epicontinental sea (Wang et al. 2006). The Early Paleozoic Ordos platform developed shallow water carbonate deposits with thicknesses of 400-1600 m (Li and Zheng 2004). In the Late Ordovician, the oceanic crust near the southern and northern portions of the North China block began to be subducted, which led to the uplift of the North China block as a whole and a hiatus in deposition during the Silurian, Devonian, and Late Cretaceous that spanned more than 130 million years (Yang et al. 2006). The Daniudi area is located on a gentle monoclonal slope called the Yishan slope in the northern Ordos Basin (Fig. 1). This area is bounded by the Yimeng uplift to the north and the Jingxi fault-fold zone to the east and covers an area of approximately $2600 \mathrm{~km}^{2}$. Its structure is a low uplift trending approximately NE-SW, with a structural crest located north of Yulin (Fig. 1).

A comprehensive summary of the stratigraphic units and their distribution in the carbonate platform is illustrated in Fig. 2a, and related information can also be found in it (Lei et al. 2010). The Ordovician carbonate rocks are divided into the following formations: Yeli, Liangjiashan, Majiagou, Pingliang, and Beiguoshan. The focus of this study is the Majiagou Formation, which is widely distributed and is subdivided into six members. The lithology in the Majiagou Formation consists of two parts: one is composed of gray muddy limestone, gypsum-bearing dolomite, and argillaceous dolomite (found in the Member 1, Member 3, and Member 5), and the other is composed of massive muddy limestone, moderately to thickly bedded muddy dolomite, and chert-band-bearing dolomite (found in the Member 2, Member 4, and Member 6). These changes in sedimentary lithology in the Majiagou Formation generally represent the carbonate rock formations of the Middle Ordovician sedimentary sequence, and the sequence can be divided into three secondary transgression-regression cycles. The Middle Ordovician carbonate rock in the Member 5 of the Majiagou Formation developed in a restricted, shallow, and hypersaline environment. The carbonates were deposited as a set of dolomite, banded 


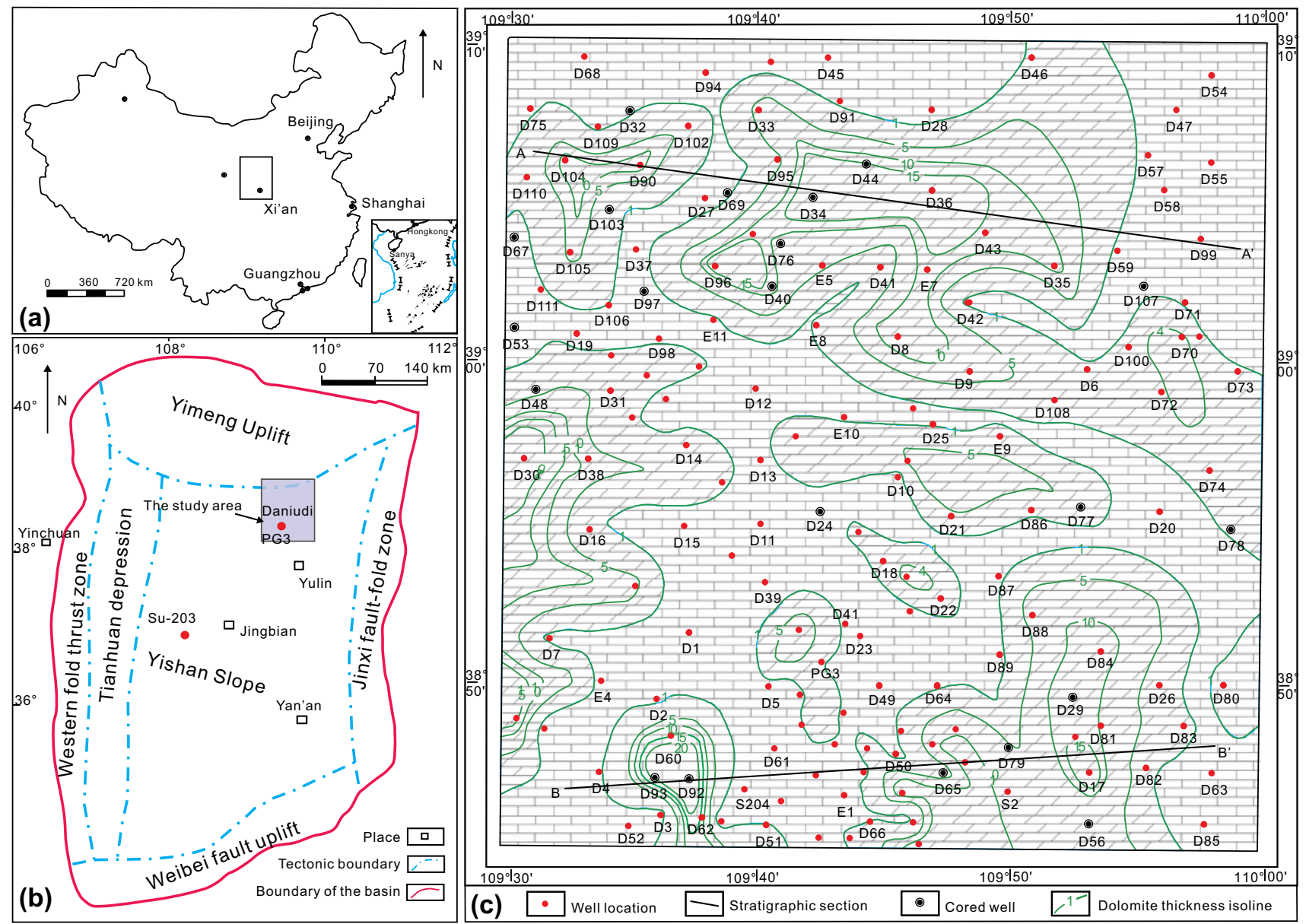

Fig. 1 a The Ordos Basin and study areas. b Sketch map of the Ordos Basin showing the location of the study area. c Detailed map showing the study area and related stratigraphic distribution, locations of wells, and dolomite distribution

limestone, and evaporated and represented the development of the regression cycles (Hu et al. 2014) (Fig. 2b).

The sedimentary facies has been studied by Feng and Bao (1999), who thought that the $\mathrm{Ma}_{5}^{5}$ submember consists of restricted, shallow marine peritidal carbonate facies and that the depositional environment includes supratidal mud flats, intertidal flats, and shallow subtidal shoals (Zhou et al. 2011). The lithology of the $\mathrm{Ma}_{5}^{5}$ submember is associated with a rapid transgression and a slow regression (Fig. 2b), and high-frequency meter-scale cycles are indicative of a restricted platform facies with subtidal and intertidal-supratidal sediment succession. The following lithofacies have been identified (Fig. 3): (1) columnar to hummocky stromatolites, peloidal mudstone, packstone, and wackestone; (2) thin-bedded to massive wackestone, rare grainstone/packstone, and laminated mudstone with fine anhydrite; and (3) bioturbated, thinbedded wackestones/mudstones with scarce fossils and finely laminated mudstone with mottled anhydrite. Normal marine bioclasts and fossils are absent from most of the succession, but dasycladacean algae, microbial laminites, benthic foraminifera, and gastropods, i.e., restricted-marine biota, occur in the $\mathrm{Ma}_{5}^{5}$ submember limestones (Fig. 3). The restricted peritidal carbonate successions lack massive evaporitic minerals (such as gypsum/anhydrite), suggesting that the $\mathrm{Ma}_{5}^{5}$ submember limestones developed in a restricted evaporitic environment with slightly increased salinity, where the marine water only rarely achieved gypsum saturation and did not reach gypsum precipitation.

\section{Methods}

Approximately 650 samples and 21 cores from the $\mathrm{Ma}_{5}^{5}$ submember in the Majiagou Formation from the Daniudi area were taken for facies, stratigraphic, and diagenetic studies. The cores were from wells at intervals of approximately $620 \mathrm{~m}$.

Approximately 140 thin sections were stained with Alizarin Red S and potassium ferricyanide to distinguish calcite and dolomite. The samples were examined using 
(a)

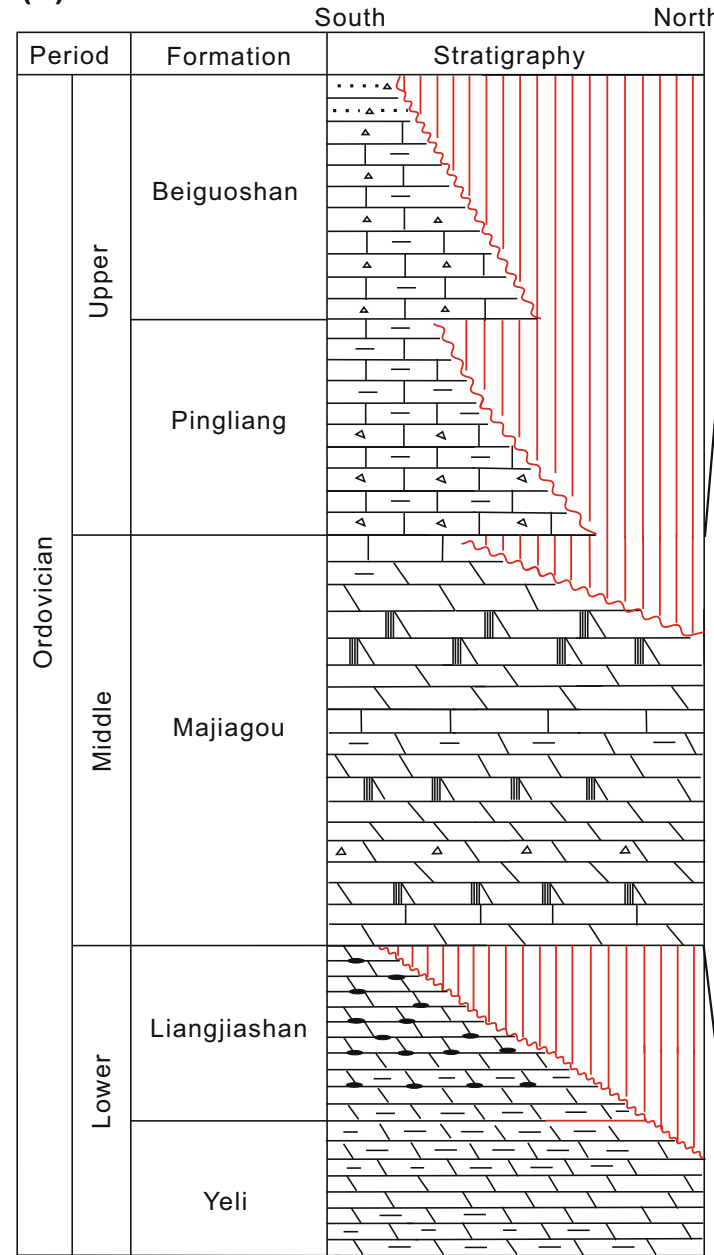

Limestone

Lime dolomite

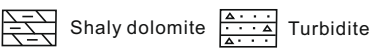

तy Dolomite (b)

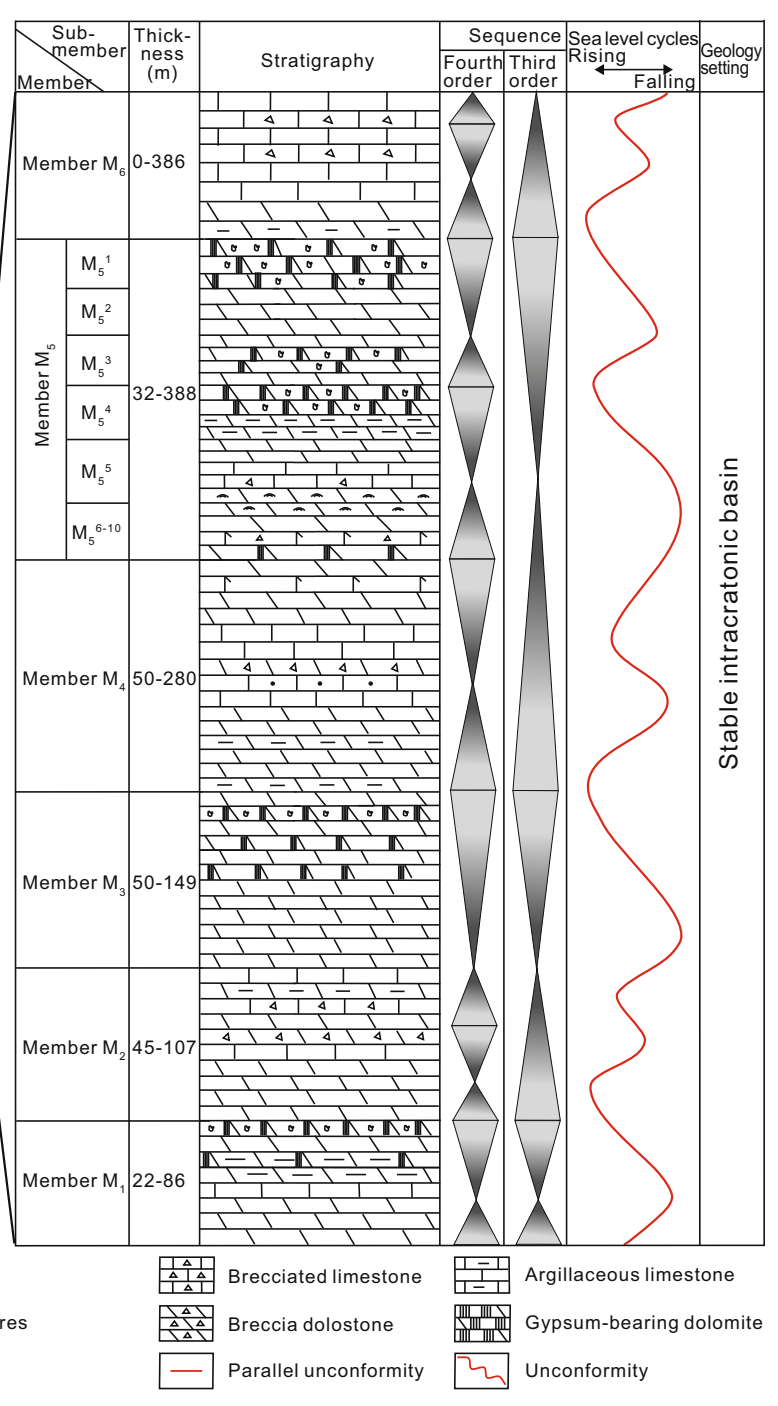

Fig. 2 Schematic diagram of the Ordovician stratigraphy and platform evolution in the Ordos Basin [Cited by Editorial Department of Chinese Stratigraphy of the Ordovician (1996)] showing the related sequence cycle changes and corresponding sea-level fluctuations in the study area

both normal and cathodoluminescent petrography with a Technosyn Cold Cathode Luminescence Model 8200 Mk II with a beam voltage of $17 \mathrm{kV}$ and a current of $600 \mu \mathrm{A}$. Blue epoxy was used to make approximately 60 thin section casts to determine the porosity. More than 300 hand specimens were collected for further detailed studies.

Forty-seven samples were drilled out with a dental drill for stable $\mathrm{C}, \mathrm{O}$, and $\mathrm{Sr}$ isotopic analysis, which was performed at the Analytical Laboratory of Beijing Research Institute of Uranium Geology. The carbon and oxygen isotope values were measured using a Finnigan Kiel-III carbonate preparation device (Perkin-Elmer Inc., Wellesley, MA, USA) directly coupled to the inlet of a Finnigan MAT 253 isotope ratio mass spectrometer. The results are reported in per mil notation relative to the Vienna Pee Dee Belemnite (VPDB) standard. The precision and calibration of the data were monitored through routine analysis of the National Bureau of Standards (NBS)-18 and NBS-19 carbonate standards. The precision was better than $\pm 0.1 \%$ internally for both the carbon and oxygen isotope values.

The ${ }^{87} \mathrm{Sr} /{ }^{86} \mathrm{Sr}$ isotope ratios of 18 samples were analyzed at the Chengdu University of Technology (CDUT, Chengdu). The $\mathrm{Sr}$ isotopic measurements were performed on a Finnigan MAT 261 instrument, and the errors associated with these analyses are reported as 2 sigma values. The maximum 2 sigma value for all of the matrix replacement $\mathrm{Sr}$ samples was \pm 0.000064 , with an average for all the samples of \pm 0.000028 . The NBS 987 standard, 


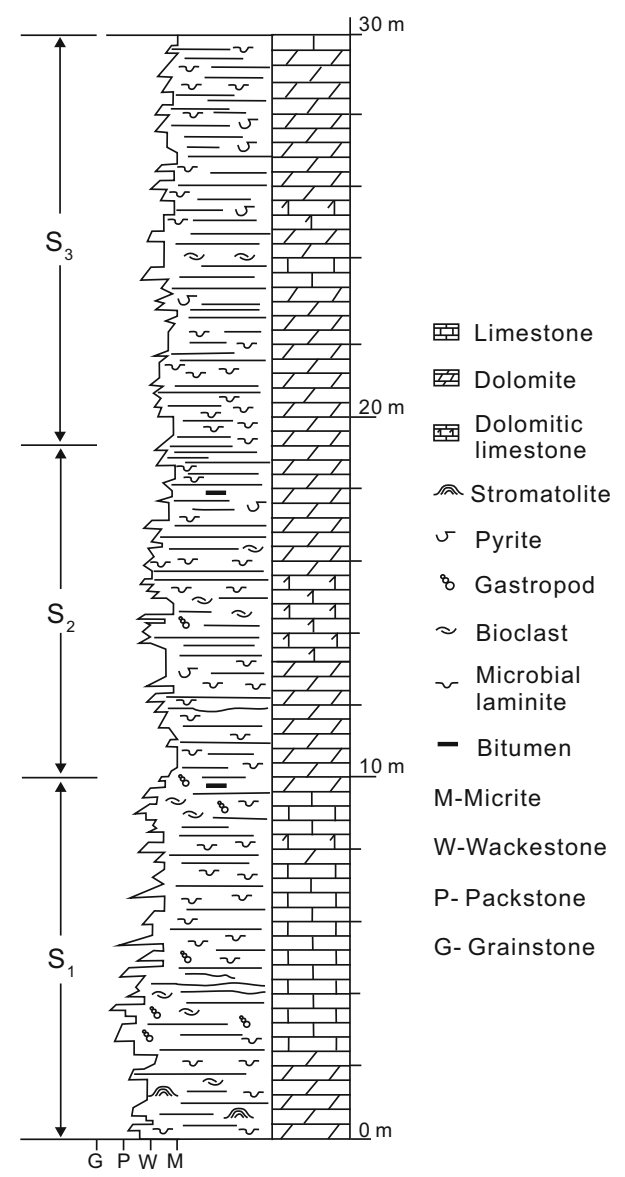

Fig. 3 Stratigraphic column of the platform carbonates in the study area. The dolomites are concentrated in the middle and upper $\mathrm{Ma}_{5}$ strata and decrease volumetrically downward. S1-S3 are the depositional sequences

which has a value of 0.710250 , yielded values between 0.710136 and 0.710312 (mean of 0.710253 ).

Major and trace element analyses were performed using a Perkin-Elmer Optima 3300 DVICP-Atomic Emission Spectrometer at the Chengdu University of Technology (CDUT, Chengdu). Multielemental high-purity solution standards were used for the calibration. An internal standard was used to correct the matrix differences. The analytical errors for $\mathrm{Ca}, \mathrm{Mg}, \mathrm{Fe}, \mathrm{Mn}, \mathrm{Sr}$, and $\mathrm{Na}$ were $\leq 0.5 \%$, $0.8 \%, 1.1 \%, 1.1 \%, 1.4 \%$, and $0.9 \%$, respectively.

\section{Dolomite petrography and distribution}

\subsection{Dolomite petrography}

The microcrystalline type 1 dolomite is characterized by euhedral to subhedral inclusion-rich dolomite (Fig. 5a). In the core samples, type 1 dolomite is generally present in algal laminae and displays preserved sedimentary fabric
(Fig. 6a, c). In thin section, type 1 dolomite is primarily characterized by microcrystalline $(<10 \mu \mathrm{m})$, euhedral dolomite crystals associated with pyrite and anhydrite. Anhydrite was replaced by the precipitation of calcite (Fig. 5b), and some very finely crystalline $(10-30 \mu \mathrm{m})$, subhedral dolomite crystals appear as bright rhombs and cut across the dolomite crystals (Fig. 5a). A few of the type 1 dolomites show algae laminae (Fig. 5c), such as algal stromatolite dolostone and algae laminae dolostone (Fig. 6a, c). The dolomite exhibits dull luminescence under CL examination.

The finely crystalline type 2 dolomite is the most abundant type of dolomite and consists of pervasively subhedral to euhedral dolomite crystals (Fig. 5d). In hand specimens, type 2 dolomite appears to have accumulated alongside stylolites and organic seams. The precursor sedimentary textures are partially to completely obliterated, and the type 2 dolomite displays visible light gray zones (Fig. 6b). In thin sections, the type 2 dolomite occurs primarily as finely crystalline $(30-100 \mu \mathrm{m})$, euhedral to subhedral dolomite crystals that were truncated by stylolites, which indicates that the type 2 dolomite most likely predated or developed alongside the stylolites (Fig. 5d, e). This type of dolomite is commonly associated with abundant intercrystalline pores (Fig. 5d) and exhibits dark red to dull luminescence (Fig. 5f).

\subsection{Dolomite distribution}

The carbonate rock of the $\mathrm{Ma}_{5}^{5}$ submember is extensively dolomitized in the study area. The interpretation of the logging data suggests that the dolomite displays extensive lateral and vertical variations (Fig. 4). The maximum dolomite thickness exceeds $20 \mathrm{~m}$ in the southern, western, and northern parts of the Daniudi area. In these locations, the microcrystalline and finely crystalline dolomites are well developed and thick (16-22 m). An examination of the cores indicates that there is a close spatial relationship between the abundances of the microcrystalline and the finely crystalline dolomites: the microcrystalline dolomite developed on top of finely crystalline dolomite, reaching substantial thicknesses, and the presence and thickness of type 2 dolomite is related to the abundance of type 1 dolomite. Type 1 dolomite is generally laminated and associated with gypsum-bearing microcrystalline dolomite that was deposited in a supratidal environment. Type 2 dolomite is primarily present as discrete, thickly bedded (6-22 $\mathrm{m})$ bodies distributed unevenly in the middle-upper part of the $\mathrm{Ma}_{5}^{5}$ submember in the carbonate platform (Fig. 4). In general, the abundance of dolomite decreases downward (Figs. 3, 4). Thin, interbedded micritic limestone/wackestone developed in the upper part and 

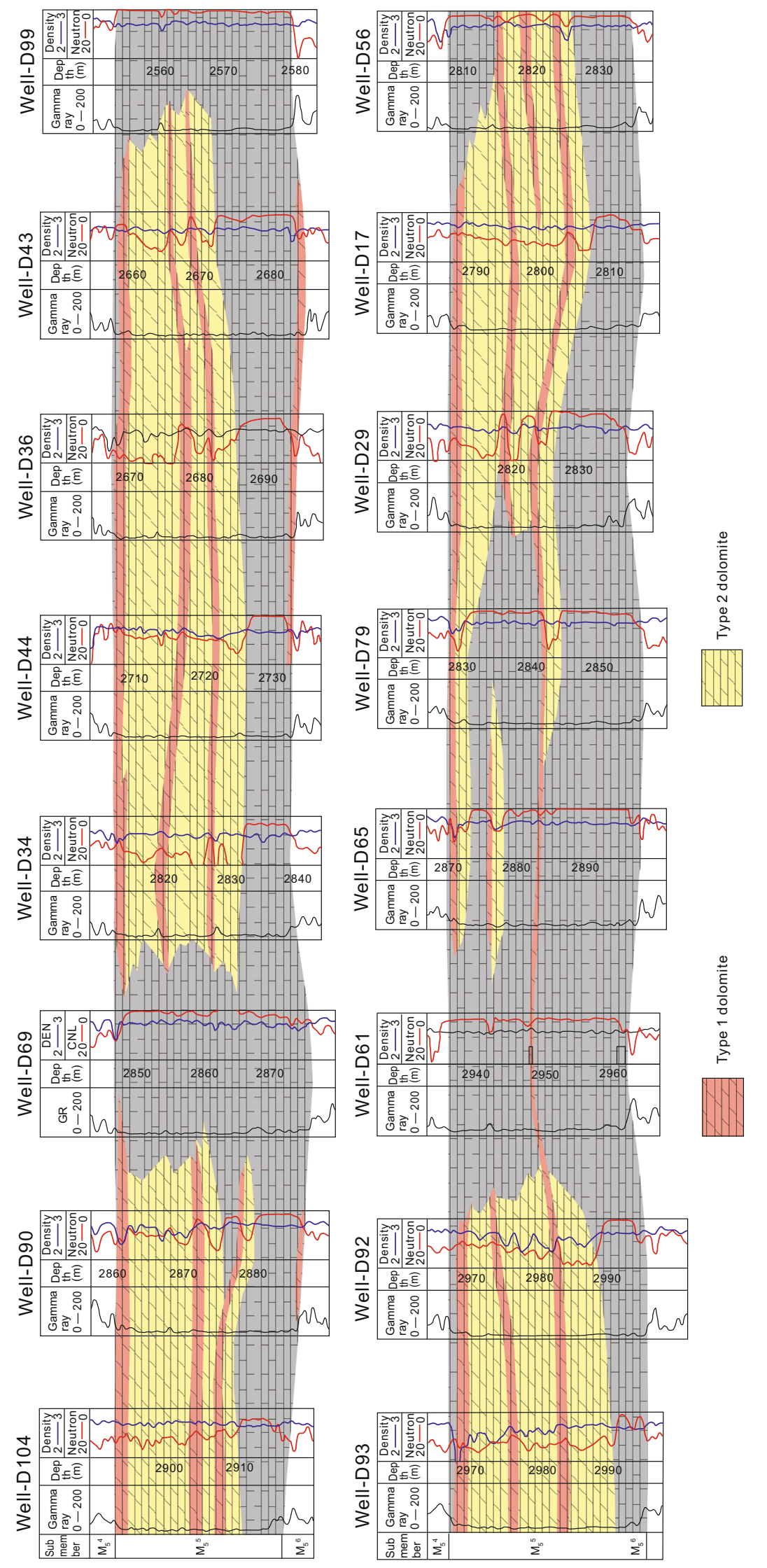

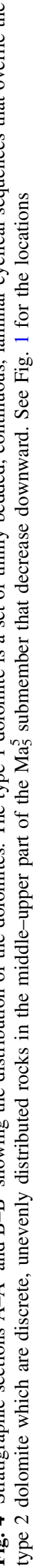
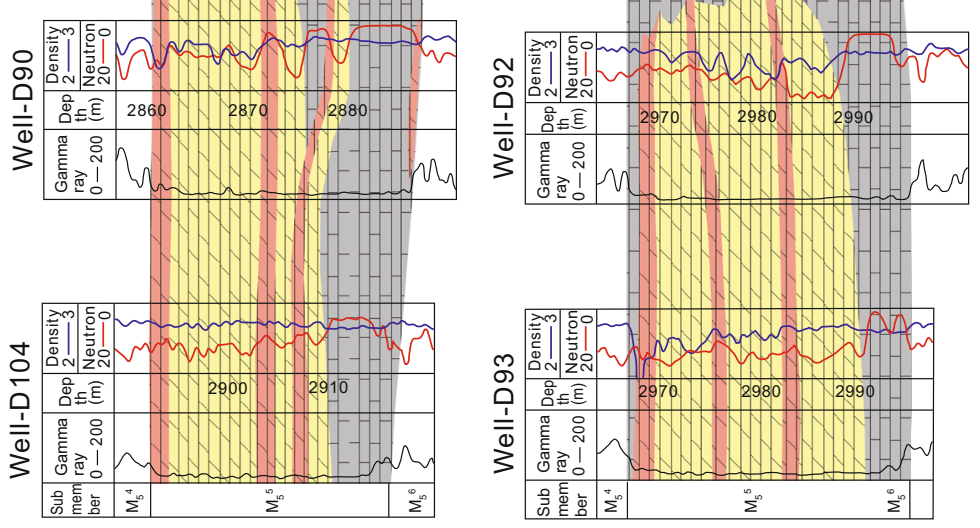
packstone/wackestone developed in the lower part of the carbonate strata in the $\mathrm{Ma}_{5}^{5}$ submember (Fig. $5 \mathrm{~g}, \mathrm{~h}$ ).

\section{Geochemical results}

\subsection{Isotope characteristics}

The stable isotope analysis results for oxygen and carbon are presented in Table 1 and Fig. 7, and the isotope analysis results for strontium are presented in Table 1 and Fig. 8. The $\delta^{18} \mathrm{O}$ and $\delta^{13} \mathrm{C}$ values of the $\mathrm{Ma}_{5}^{5}$ submember limestone overlap with the estimated $\delta^{18} \mathrm{O}$ and $\delta^{13} \mathrm{C}$ ranges of the Middle Ordovician marine limestone (Qing and Veizer 1994; Veizer et al. 1999). Oxygen isotope difference between calcite and coevally precipitated dolomite is approximately $2.5 \%$ (Swart and Melim 2000); thus, dolomites precipitated from normal Middle Ordovician seawater should have $\delta^{18} \mathrm{O}$ values between -7.0 and $-5.0 \%$ PDB (Fig. 7). The ${ }^{87} \mathrm{Sr} /{ }^{86} \mathrm{Sr}$ ratios of the $\mathrm{Ma}_{5}^{5}$ submember limestone fall within the estimated ${ }^{87} \mathrm{Sr} /{ }^{86} \mathrm{Sr}$ range (0.7078-0.7093) of the Middle Ordovician marine carbonates (Qing et al. 1998; Veizer et al. 1999; McArthur et al. 2001; Davies and Smith 2006). These data indicate that the ${ }^{87} \mathrm{Sr} /{ }^{86} \mathrm{Sr}$ ratios and $\delta^{13} \mathrm{C}$ and $\delta^{18} \mathrm{O}$ values of the $\mathrm{Ma}_{5}^{5}$ submember limestone can be used as a baseline for Middle Ordovician marine carbonate deposits.

The type 2 dolomite yields $\delta^{18} \mathrm{O}$ values ranging from -8.5 to $-6.7 \%$ (average $-7.5 \%$ ), lower than those of the type 1 dolomite (Table 1 ). The ${ }^{87} \mathrm{Sr} /{ }^{86} \mathrm{Sr}$ ratios of the type 1 and type 2 dolomites are slightly higher than those of the limestone.

\subsection{Major and trace elements}

The results of the trace element concentration analyses are presented in Table 2. The average $\mathrm{Sr}, \mathrm{Na}, \mathrm{Fe}$, and $\mathrm{Mn}$ concentrations in the $\mathrm{Ma}_{5}^{5}$ submember limestone are 209, 274, 308, and $26 \mathrm{ppm}$, respectively (Table 2). The type 1 dolomite contains $\mathrm{Ca}^{2+}$ molar concentrations ranging from $54.3 \%$ to $62.6 \%$ (average $59.1 \%$ ), higher than those of the type 2 dolomite, which range from $50.8 \%$ to $55.7 \%$ (average $54.3 \%$ ). The type 2 dolomite has higher $\mathrm{Fe}$ and $\mathrm{Mn}$ concentrations and lower $\mathrm{Sr}$ and $\mathrm{Na}$ concentrations than the type 1 dolomite.

\section{Discussion and interpretation}

\subsection{Petrographic implications}

Type 1 dolomite is primarily characterized by microcrystalline $(<30 \mu \mathrm{m})$, euhedral to subhedral dolomite crystals associated with anhydrite that has been replaced by the precipitation of calcite (Fig. 5b). It has been suggested that microcrystalline dolomite may form in evaporitic settings at relatively low temperatures (Gregg and Shelton 1990; Fu et al. 2006; Loyd and Corsetti 2010). The appearance of restricted-marine biota with laminar, distorted, green stromatolite algae indicates that the original structure of the limestone has been retained in the microcrystalline dolomite, which most likely originated from near-surface dolomitization in a restricted, shallow environment during early diagenesis (Fig. 5c). Type 1 dolomite pervasively replaces the matrix of all the facies, particularly those associated with the complete replacement of laminites. The textures of the type 1 dolomite and its close association with the restricted-marine deposits suggest that this type of dolomite most likely formed in a near-surface, low-temperature, saline environment with a high density of nucleation sites (Gregg and Shelton 1990). The very finely crystalline $(10-30 \mu \mathrm{m})$, subhedral dolomite rhombs are interpreted as partial recrystallization during burial based on petrographic observations. The finely crystalline bright rhombs appear to cut across the subhedral dolomite crystals (Fig. 5a), suggesting that the recrystallization of very fine dolomite postdates the early penecontemporaneous dolomite.

Type 2 dolomite is present primarily as finely crystalline (30-100 $\mu \mathrm{m})$, euhedral to subhedral dolomite crystals that preferentially replaced the limestone matrix. The type 2 dolomites are characterized by partial to complete replacement of muddy limestone/wackestone (Fig. $5 \mathrm{~g}, \mathrm{~h}$ ). This phenomenon suggests that the dolomitizing fluids were somewhat less supersaturated with respect to dolomite or insufficient for complete dolomitization. The dolomite commonly exhibits destruction of the fabric and indistinct original depositional features (Fig. 5d). The crystals in type 2 dolomite are truncated by the early stylolites, which indicates that the type 2 dolomite most likely predated or developed simultaneously with the formation of the stylolites (Fig. 5e). The early stylolites in the carbonate rocks may have developed at $<300 \mathrm{~m}$ depth (Fabricius and Borre 2007), which indicates that the type 2 dolomite formed during a period of shallow burial.

\subsection{Stratigraphic constraints}

The type 1 dolomites in the $\mathrm{Ma}_{5}^{5}$ submember have been shown to have formed in an evaporite-restricted condition based on their stratigraphic relationships. Type 1 dolomite is primarily represented by laminated, distorted green algae, and gypsum-bearing muddy dolomite originating in a supratidal environment (Figs. 5b, c, 6a), and its textural characteristics and geographic distribution may be correlated with the composite sea-level changes recorded in the 

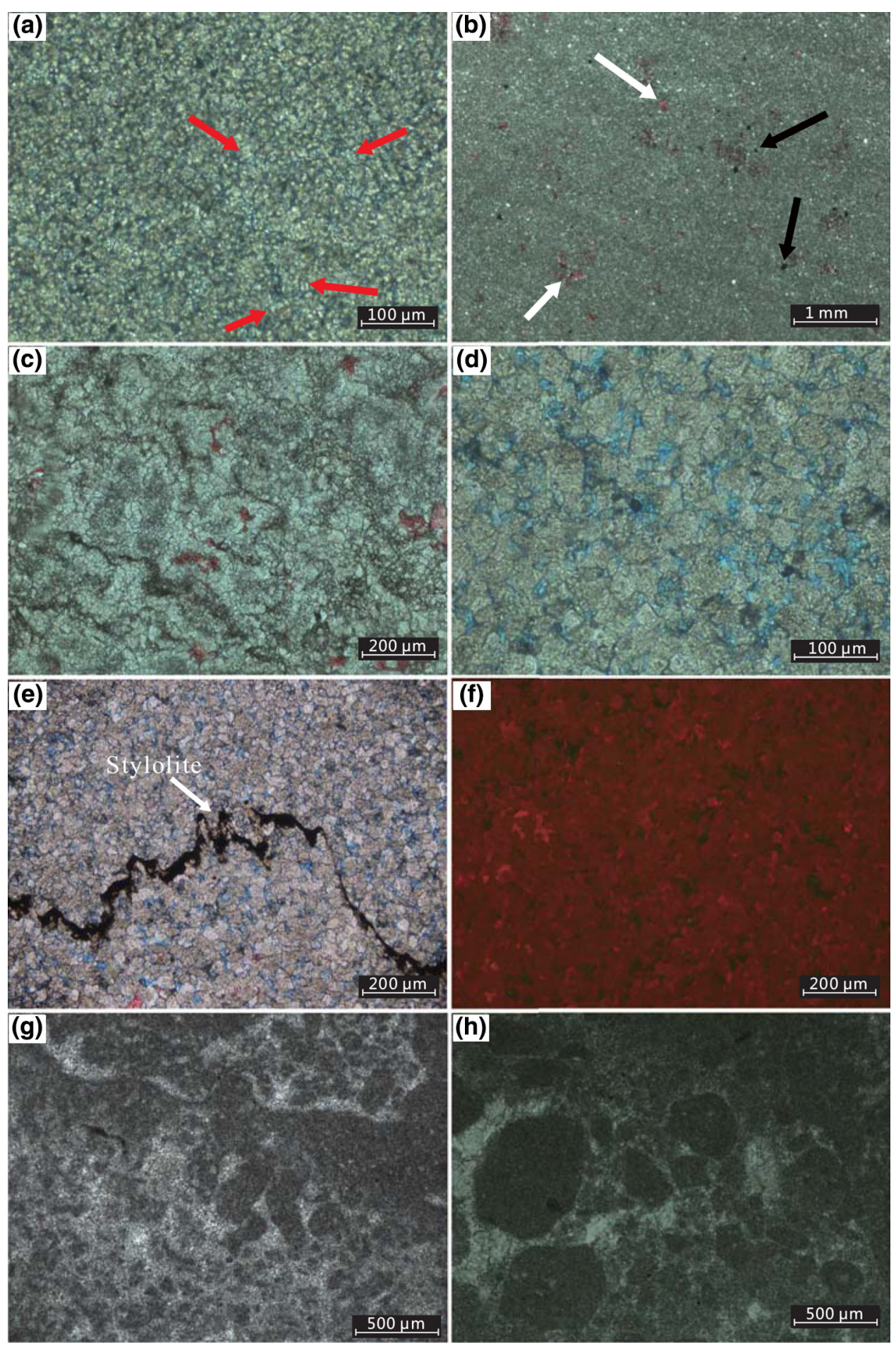

Fig. 5 Photomicrographs showing the petrographic characteristics of the dolomite. a Peloidal packstone-wackestone that developed in the lower part of the whole $\mathrm{M}_{5}^{5}$ submember carbonate strata. b Peloidal grainstone that is cemented by fine equant calcite cement, which is related to early marine cementation. c Type 1 dolomite that is primarily characterized by microcrystalline $(<30 \mu \mathrm{m})$, euhedral to subhedral dolomite crystals. $\mathbf{d}$ Layered type 1 dolomite that is associated with pyrite and anhydrite, and the anhydrite is replaced by the precipitation of calcite, though some retain the algal laminae structure. $\mathbf{e}$ Laminar algal dolomite that is characterized by crumpled textures and retains the original features and primary sedimentary structures. $\mathbf{f}$ Type 2 dolomite that is primarily present as finely crystalline $(30-100 \mu \mathrm{m})$, regular crystal plane, euhedral to subhedral dolomite crystals with abundant intercrystalline pores; this type 2 dolomite commonly exhibits the destruction of the fabric and indistinct original depositional features as a result of diagenesis. $\mathbf{g}$ Type 2 dolomite that occurs primarily as finely crystalline, euhedral to subhedral dolomite crystals that were truncated by stylolites. This indicates that the $\mathrm{Rd} 2$ dolomite most likely predated or developed alongside the stylolites. $\mathbf{h}$ Type 2 dolomite that exhibits dull to dark red luminescence, with calcite cement pore fillings displaying orange luminescence 
carbonate succession (Figs. 2b, 3). The $\mathrm{Ma}_{5}^{5}$ submember deposits were largely replaced by type 1 dolomite on the shallow water carbonate platform, whereas the thinly bedded dolomite sequences (Fig. 4) and the lack of massive gypsum/anhydrite suggest that the type 1 dolomite formed from penesaline seawater in a near-surface environment, with magnesium ions provided by a combination of high- and low-frequency sea-level changes (Qing et al. 2001). The development of dolomite in a zone of mixed meteoric and marine water has been questioned and considered to be unlikely by many researchers (Hardie 1987; Melim et al. 2004). A mixed water process for dolomitization is not consistent with the type 1 dolomite, particularly because the dolomite strata in the $\mathrm{Ma}_{5}^{5}$ submember are generally approximately horizontal rather than present as lenses (as in the mixing zone model) or related to unconformities.

The geometric configurations and distribution of the type 2 dolomite bodies are apparent constraints on the origin of the dolomite (Warren 2000). Type 2 dolomite is primarily present as discrete, unevenly distributed rocks in the middle-upper part of the $\mathrm{Ma}_{5}^{5}$ submember (Fig. 4), and its distribution and abundance are closely related to those of the type 1 dolomite. Type 1 dolomite is present as a set of thinly bedded, continuous, laminar algal subtidal-intertidal cyclical sequences that overlie the type 2 dolomite and are associated with a downward decrease in the abundance of the type 2 dolomite (Figs. 3, 4). This association suggests that the dolomitizing fluids may have originated in the overlying strata. Another possibility is that type 2 dolomite developed as a result of the minor to extensive modification of type 1 dolomite. Studies suggest that early-formed dolomites in ancient carbonates commonly experience diagenetic modification (stabilization or recrystallization) (Rott and Qing 2013).

\subsection{Implications of the geochemical data}

The type 1 dolomite yields $\delta^{18} \mathrm{O}$ values ranging from -7.5 to $-6.1 \%$ (average $-6.86 \%$ ), which are higher than the estimated values of the Middle Ordovician marine limestone -9.5 to $-7.5 \%$ ) (Table 1; Fig. 7) and slightly lower than those of dolomite precipitated from Middle Ordovician seawater. Therefore, the dolomite may be related to dolomite recrystallization at higher temperatures during burial, but the replacement of the carbonate sediments by dolomitizing fluids took place in the early contemporaneous seawater. The $\delta^{13} \mathrm{C}$ values and ${ }^{87} \mathrm{Sr} /{ }^{86} \mathrm{Sr}$ ratios in the type 1 dolomite are comparable with those in the corresponding limestone in the $\mathrm{Ma}_{5}^{5}$ submember and were inherited from the precursor limestone (Fig. 7). The $\delta^{13} \mathrm{C}$ values of carbonates are usually rock-buffered during diagenesis if no significant amount of organic $\mathrm{CO}_{2}$ is involved
(Banner and Hanson 1990; Warren 2000). The appearance of algae laminae with rare gypsum pseudomorphs suggests that the type 1 dolomite formed in a near-surface, lowtemperature, and penesaline environment.

The type 2 dolomite yields carbon isotopic values that overlap with the estimated values of the Middle Ordovician marine limestone in the $\mathrm{Ma}_{5}^{5}$ submember, which is interpreted to reflect the carbon isotopic compositions of the precursor limestone and type 1 dolomite. However, the type 2 dolomite displays lower $\delta^{18} \mathrm{O}$ values and higher ${ }^{87} \mathrm{Sr} /{ }^{86} \mathrm{Sr}$ ratios compared to the type 1 dolomite (Fig. 8). The more negative $\delta^{18} \mathrm{O}$ values have two causes, namely, dolomitization at deeper burial depths and elevated temperatures or the participation of fresh water (Gregg and Shelton 1990; Durocher and Al-Aasm 1997). It is unlikely that meteoric water was responsible for the low $\delta^{18} \mathrm{O}$ values in the type 2 dolomite based on its petrographic features and the lack of evidence of meteoric diagenesis. The shift to depleted $\delta^{18} \mathrm{O}$ values in the type 2 dolomite was most likely due to recrystallization at elevated temperatures during burial. The higher ${ }^{87} \mathrm{Sr} /{ }^{86} \mathrm{Sr}$ ratios in the type 2 dolomite relative to the type 1 dolomite are most likely related to recrystallization in more radiogenic pore water with slightly elevated ${ }^{87} \mathrm{Sr} /{ }^{86} \mathrm{Sr}$ ratios.

The type 1 dolomites $(54.3 \%-62.6 \%$, average $59.1 \%$ mol\% $\left.\mathrm{CaCO}_{3}\right)$ are typically nonstoichiometric, and the type 2 dolomites have more stoichiometric compositions $\left(50.8 \%-55.7 \%\right.$, average $\left.54.3 \% \mathrm{~mol} \% \mathrm{CaCO}_{3}\right)$ than type 1 dolomites, indicating that these rocks underwent diagenetic modification (Table 2; Fig. 9). It is possible that the nearly stoichiometric compositions of the type 2 dolomites are due to the recrystallization of dolomites or dolomitization in pore water during burial. Studies have suggested that this stoichiometry is a function of both the chemistry and the duration of interaction with dolomitizing/stabilizing fluids (Sibley 1990). In addition, the Ca concentrations in syndepositional dolomites decrease with increasing crystal size (Warren 2000). These previous findings suggest that the initially Ca-rich type 1 dolomite formed near the surface during a period of rapid penecontemporaneous crystallization and that the type 2 dolomite formed via the recrystallization of dolomites or via dolomitization during burial. The $\mathrm{Sr}$ concentrations of the type 2 dolomites (69-124 ppm, average $92 \mathrm{ppm}$ ) are lower than those of the evaporitic marine type 1 dolomite (138-190 ppm, average $165 \mathrm{ppm})$. Recrystallization and dolomitization assist in stoichiometric enhancement and commonly lower the $\mathrm{Sr}$ concentrations in dolomite due to the low distribution coefficient of this element $(<<1)$, a low $\mathrm{Sr} / \mathrm{Ca}$ ratio in the solutions, and/or low reaction rates (Banner 1995) (Fig. 10).

The $\mathrm{Na}$ concentrations in the type 1 dolomite (387-559 ppm) are significantly higher than those in the 
Table 1 Isotope data of the $\mathrm{Ma}_{5}^{5}$ submember carbonate rocks in the Daniudi area

\begin{tabular}{|c|c|c|c|c|c|c|}
\hline Well number & Lithology & Strata & Depth, m & $\delta^{18} \mathrm{O}, \%$ (PDB) & $\delta^{13} \mathrm{C}, \%$ (PDB) & $\mathrm{Sr}^{87} / \mathrm{Sr}^{86}( \pm \mathrm{SE})$ \\
\hline D92 & Type 1 dolomite & $\mathrm{Ma}_{5}^{5}$ & 2970.44 & -6.7 & -0.1 & \\
\hline D92 & Type 1 dolomite & $\mathrm{Ma}_{5}^{5}$ & 2985.45 & -6.2 & -0.1 & \\
\hline D56 & Type 1 dolomite & $\mathrm{Ma}_{5}^{5}$ & 2826.1 & -6.6 & -0.6 & \\
\hline D56 & Type 1 dolomite & $\mathrm{Ma}_{5}^{5}$ & 2825.4 & -6.2 & -0.3 & \\
\hline D92 & Type 1 dolomite & $\mathrm{Ma}_{5}^{5}$ & 2984.38 & -6.4 & -0.2 & \\
\hline D92 & Type 1 dolomite & $\mathrm{Ma}_{5}^{5}$ & 2983.97 & -6.1 & -0.1 & \\
\hline D65 & Type 1 dolomite & $\mathrm{Ma}_{5}^{5}$ & 2871.55 & -7.2 & -0.7 & \\
\hline D65 & Type 1 dolomite & $\mathrm{Ma}_{5}^{5}$ & 2871.7 & -7.1 & -0.8 & \\
\hline D56 & Type 1 dolomite & $\mathrm{Ma}_{5}^{5}$ & 2836.61 & -6.8 & -0.5 & $0.709242 \pm 0.000064$ \\
\hline D78 & Type 1 dolomite & $\mathrm{Ma}_{5}^{5}$ & 2637.96 & -7.0 & -0.4 & $0.709128 \pm 0.000098$ \\
\hline D92 & Type 1 dolomite & $\mathrm{Ma}_{5}^{5}$ & 2973.28 & -7.5 & -1.0 & $0.709326 \pm 0.000052$ \\
\hline D32 & Type 1 dolomite & $\mathrm{Ma}_{5}^{5}$ & 2881.82 & -7.0 & -0.6 & \\
\hline D32 & Type 1 dolomite & $\mathrm{Ma}_{5}^{5}$ & 2884.05 & -7.1 & -0.1 & \\
\hline D29 & Type 1 dolomite & $\mathrm{Ma}_{5}^{5}$ & 2834.55 & -6.6 & -0.8 & $0.709082 \pm 0.000072$ \\
\hline D53 & Type 1 dolomite & $\mathrm{Ma}_{5}^{5}$ & 3012.5 & -7.2 & -1.0 & $0.709224 \pm 0.000065$ \\
\hline D78 & Type 1 dolomite & $\mathrm{Ma}_{5}^{5}$ & 2638.56 & -6.5 & -0.6 & $0.709148 \pm 0.000024$ \\
\hline D78 & Type 1 dolomite & $\mathrm{Ma}_{5}^{5}$ & 2643.32 & -6.6 & -0.5 & $0.709168 \pm 0.000012$ \\
\hline D65 & Type 2 dolomite & $\mathrm{Ma}_{5}^{5}$ & 2873.44 & -7.0 & 0.3 & \\
\hline D56 & Type 2 dolomite & $\mathrm{Ma}_{5}^{5}$ & 2842.67 & -8.5 & 0.4 & \\
\hline D48 & Type 2 dolomite & $\mathrm{Ma}_{5}^{5}$ & 3009.53 & -7.4 & 0.3 & \\
\hline D48 & Type 2 dolomite & $\mathrm{Ma}_{5}^{5}$ & 3013.65 & -7.3 & 0 & \\
\hline D48 & Type 2 dolomite & $\mathrm{Ma}_{5}^{5}$ & 3017.32 & -7.1 & -0.6 & \\
\hline D48 & Type 2 dolomite & $\mathrm{Ma}_{5}^{5}$ & 3023.54 & -8.1 & 0.1 & \\
\hline D44 & Type 2 dolomite & $\mathrm{Ma}_{5}^{5}$ & 2720.31 & -7.7 & 0.1 & $0.709382 \pm 0.000072$ \\
\hline D44 & Type 2 dolomite & $\mathrm{Ma}_{5}^{5}$ & 2720.98 & -7.5 & 0.1 & $0.709404 \pm 0.000044$ \\
\hline D44 & Type 2 dolomite & $\mathrm{Ma}_{5}^{5}$ & 2722.3 & -7.9 & -0.1 & $0.709485 \pm 0.000054$ \\
\hline D44 & Type 2 dolomite & $\mathrm{Ma}_{5}^{5}$ & 2723.07 & -6.9 & 0.2 & $0.709188 \pm 0.000072$ \\
\hline D29 & Type 2 dolomite & $\mathrm{Ma}_{5}^{5}$ & 2819.74 & -7.3 & -0.6 & $0.709326 \pm 0.000026$ \\
\hline D48 & Type 2 dolomite & $\mathrm{Ma}_{5}^{5}$ & 3013.65 & -7.2 & -0.5 & $0.709254 \pm 0.000090$ \\
\hline D48 & Type 2 dolomite & $\mathrm{Ma}_{5}^{5}$ & 3014.88 & -7.5 & -0.9 & \\
\hline D78 & Type 2 dolomite & $\mathrm{Ma}_{5}^{5}$ & 2639.06 & -7.9 & -0.4 & $0.709308 \pm 0.000034$ \\
\hline D78 & Type 2 dolomite & $\mathrm{Ma}_{5}^{5}$ & 2639.44 & -8 & -0.3 & \\
\hline D78 & Type 2 dolomite & $\mathrm{Ma}_{5}^{5}$ & 2638.20 & -7.7 & -0.3 & \\
\hline D78 & Type 2 dolomite & $\mathrm{Ma}_{5}^{5}$ & 2638.68 & -7.9 & -0.2 & \\
\hline D65 & Type 2 dolomite & $\mathrm{Ma}_{5}^{5}$ & 2872.32 & -7.5 & -0.3 & \\
\hline D65 & Type 2 dolomite & $\mathrm{Ma}_{5}^{5}$ & 2872.97 & -7.8 & 0.2 & \\
\hline D65 & Type 2 dolomite & $\mathrm{Ma}_{5}^{5}$ & 2873.45 & -7.6 & -0.6 & \\
\hline D65 & Limestone & $\mathrm{Ma}_{5}^{5}$ & 2873.82 & -8.8 & -1.3 & \\
\hline D53 & Limestone & $\mathrm{Ma}_{5}^{5}$ & 2986.14 & -8.7 & -0 & \\
\hline D53 & Limestone & $\mathrm{Ma}_{5}^{5}$ & 2987.97 & -8.5 & -1.0 & \\
\hline D53 & Limestone & $\mathrm{Ma}_{5}^{5}$ & 2994.5 & -8.3 & -0.4 & \\
\hline D53 & Limestone & $\mathrm{Ma}_{5}^{5}$ & 3003.7 & -8.3 & -0.1 & \\
\hline D29 & Limestone & $\mathrm{Ma}_{5}^{5}$ & 2831.5 & -9.0 & -1.5 & $0.708992 \pm 0.000084$ \\
\hline D29 & Limestone & $\mathrm{Ma}_{5}^{5}$ & 2821.95 & -9.2 & -0.9 & $0.709158 \pm 0.000036$ \\
\hline D56 & Limestone & $\mathrm{Ma}_{5}^{5}$ & 2831.61 & -7.9 & -0.1 & $0.708998 \pm 0.000052$ \\
\hline D101 & Limestone & $\mathrm{Ma}_{5}^{5}$ & 2777.00 & -7.8 & -1.4 & $0.709106 \pm 0.000045$ \\
\hline D92 & Limestone & $\mathrm{Ma}_{5}^{5}$ & 2990.55 & -9.0 & -2.1 & \\
\hline
\end{tabular}


Table 2 Elemental concentrations of the $\mathrm{Ma}_{5}^{5}$ submember carbonate rocks in the Daniudi area

\begin{tabular}{|c|c|c|c|c|c|c|c|c|}
\hline Well number & Lithology & $\mathrm{Ca}, \mathrm{mol} \%$ & $\mathrm{Ca}, \mathrm{ppm}$ & $\mathrm{Mg}, \mathrm{ppm}$ & $\mathrm{Na}, \mathrm{ppm}$ & $\mathrm{Fe}, \mathrm{ppm}$ & $\mathrm{Sr}, \mathrm{ppm}$ & $\mathrm{Mn}, \mathrm{ppm}$ \\
\hline D29 & Limestone & 99.2 & 434,600 & 2040 & 234 & 406 & 158 & 26 \\
\hline D29 & Limestone & 99.0 & 422,400 & 2640 & 292 & 420 & 152 & 18 \\
\hline D56 & Limestone & 99.0 & 353,900 & 2220 & 274 & 260 & 144 & 17 \\
\hline D101 & Limestone & 98.7 & 420,400 & 3300 & 297 & 145 & 171 & 42 \\
\hline D29 & Type 1 dolomite & 62.6 & 257,600 & 92,400 & 514 & 1565 & 138 & 50 \\
\hline D53 & Type 1 dolomite & 61.9 & 278,800 & 103,100 & 444 & 910 & 153 & 44 \\
\hline D56 & Type 1 dolomite & 56.5 & 245,800 & 113,400 & 387 & 1145 & 146 & 40 \\
\hline D78 & Type 1 dolomite & 58.9 & 245,900 & 102,800 & 455 & 876 & 152 & 42 \\
\hline D92 & Type 1 dolomite & 61.4 & 269,700 & 101,600 & 559 & 1685 & 169 & 48 \\
\hline D78 & Type 1 dolomite & 59.2 & 248,400 & 102,800 & 442 & 1325 & 190 & 44 \\
\hline D44 & Type 1 dolomite & 54.3 & 219,700 & 110,900 & 442 & 1270 & 188 & 56 \\
\hline D78 & Type 1 dolomite & 58.0 & 225,600 & 98,000 & 437 & 1837 & 181 & 53 \\
\hline D29 & Type 2 dolomite & 55.0 & 229,000 & 112,300 & 392 & 2237 & 94 & 52 \\
\hline D48 & Type 2 dolomite & 55.7 & 249,400 & 118,800 & 434 & 1948 & 69 & 79 \\
\hline D78 & Type 2 dolomite & 55.3 & 233,900 & 113,300 & 409 & 1973 & 104 & 54 \\
\hline D44 & Type 2 dolomite & 50.8 & 200,400 & 116,500 & 349 & 1682 & 92 & 62 \\
\hline D44 & Type 2 dolomite & 54.5 & 224,600 & 112,400 & 465 & 2042 & 124 & 70 \\
\hline D44 & Type 2 dolomite & 54.4 & 220,900 & 111,100 & 462 & 2491 & 69 & 80 \\
\hline
\end{tabular}

$\mathrm{Ma}_{5}^{5}$ submember limestone (average $274 \mathrm{ppm}$ ) and are similar to those in the type 2 dolomite (349-465 ppm), which is inferred to have formed from evaporitic or slightly modified seawater (Staudt et al. 1993). The Na concentrations in dolomite generally increase with the salinity of dolomitizing fluids and decrease with stoichiometric enhancement (Mazzullo 1992). However, the distribution coefficient of the Na concentrations in dolomite is not well known (Wheeler et al. 1989). The variable Na concentrations in dolomite may not reflect changes in the salinity of the dolomitizing fluids, and the $\mathrm{Na}$ concentrations during dolomitization are not useful indicators of the chemistry of the parent fluid (Wheeler et al. 1989; Fu et al. 2006).

The Fe and Mn concentrations in the type 2 dolomites are higher than those in the type 1 dolomites and the $\mathrm{Ma}_{5}^{5}$ submember limestone, suggesting that the dolomitic fluids in the pore water were slightly reducing, incorporating $\mathrm{Fe}^{2+}$ and $\mathrm{Mn}^{2+}$ more easily into the crystal lattice. The high concentrations of $\mathrm{Mn}$ and $\mathrm{Fe}$ in the type 2 dolomites and the lower concentrations of $\mathrm{Mn}$ and $\mathrm{Fe}$ in the precursor limestone show that there were no significant sources of these elements, which suggests that the dolomitic fluids precipitated under slightly reducing conditions or that the dolomite formed in a late burial environment (Warren 2000; Franzolin et al. 2012) (Fig. 11).

\subsection{Hydrology of the dolomitizing fluids}

The hydrology of dolomitizing fluids is such that dolomitization requires both the active circulation of $\mathrm{Mg}$-rich fluids and favorable geochemical conditions to overcome kinetic barriers to dolomitization (McKenzie 1980). Dolomite associated with evaporites is commonly interpreted to be related to brine seepage reflux (Warren 2000; $\mathrm{Fu}$ et al. 2006). The type 1 dolomite is primarily represented by laminated, meter-scale, peritidal, cyclic, gypsumbearing muddy dolomite deposited in a supratidal environment. It is suggested that the type 1 dolomite formed in marine conditions of slightly elevated salinity and that the dolomitization may have occurred in extensive platformtop environments associated with the repeated flooding and reflux of marine water with slightly higher salinity (Friedman and Sun 1995). The flux distribution varies by orders of magnitude along the flow path (Jones and Rostron 2000). The discontinuous (lengths of 40-50 km and widths of $20-30 \mathrm{~km}$ ), meter-scale, stratiform dolomites were controlled by fourth- or fifth-order regressions associated with major storms during which seawater was transported tens of kilometers (Montañez and Read 1992). The stratigraphic distribution of the dolomite was also controlled by its position within third-order depositional sequences during the early deposition of the $\mathrm{Ma}_{5}$ member (Fig. 2b). The regressive facies of the third-order sequences tends to be represented primarily by dolomite, whereas the transgressive facies retains abundant limestone (Montañez and Read 1992). The reflux model is based on the presence of transgressive facies in third-order depositional sequences with fourth- or fifth-order regressions (Fig. 2b). This regional-scale reflux is a viable mechanism for regionalscale dolomitization during shallow burial $(<500 \mathrm{~m})$ 

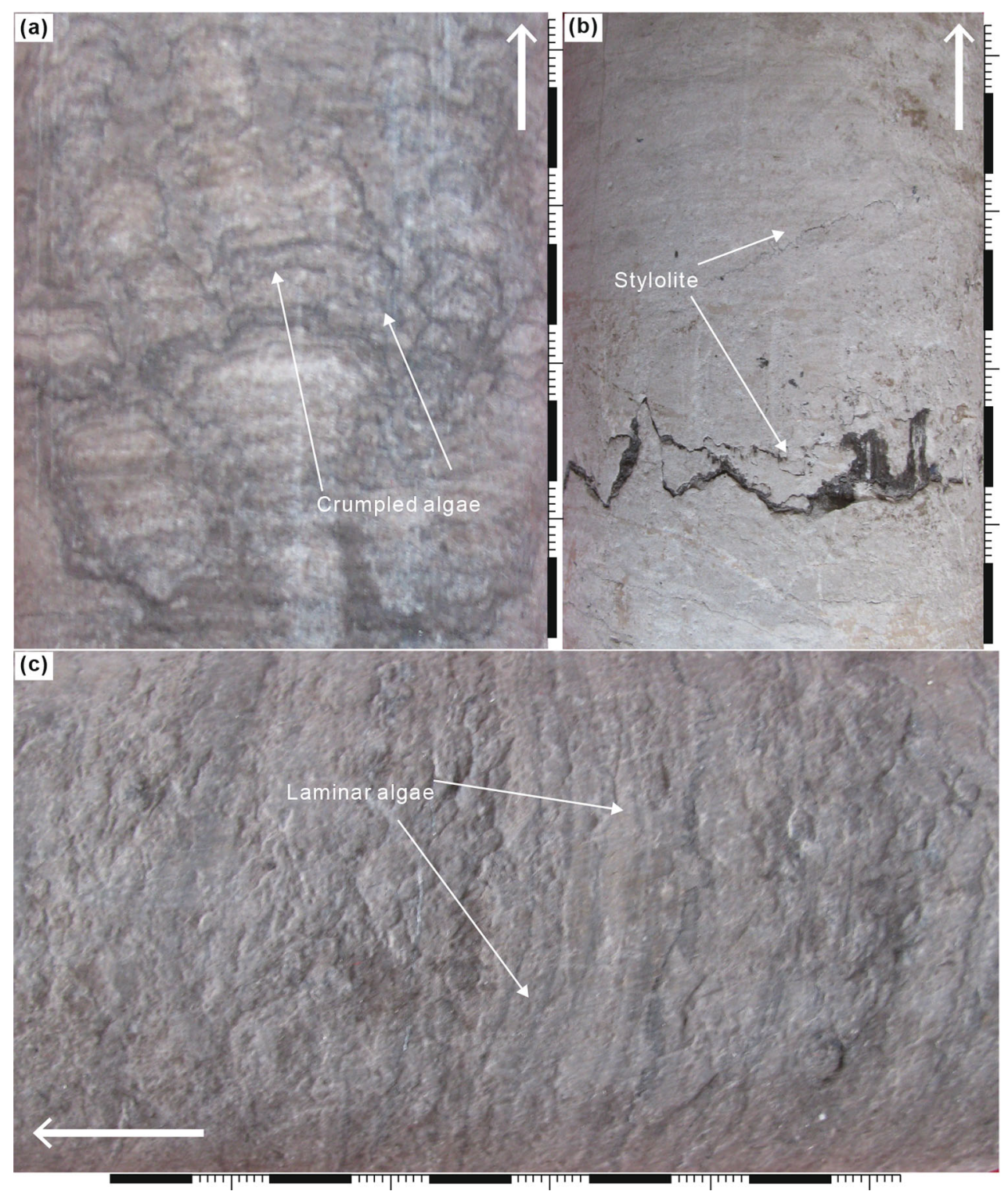

Fig. 6 Photomicrographs showing the depositional characteristics of the dolomite. a Laminar algal dolomite with stromatolites that are characterized by crumpled textures and retain the original features and primary sedimentary structures, displaying a gradual upward-deepening sequence. b Type 2 dolomite that appears to have accumulated alongside stylolites; the organic seams may be contemporaneous with the early stylolites. c Continuous, well-laminated dolomite that generally developed in the algal laminae in the supralittoral zone and may preserve the sedimentary fabric

(Haeri-Ardakani et al. 2013). Seawater with slightly elevated salinity can result in the generation of dense platform-top brines. These dense brines are potential dolomitizing fluids that can descend into underlying pore networks under the influence of gravity. However, the flow of diagenetic fluids critically depends on spatial variations in the permeability, generating complex dolomite bodies at a range of scales (Al-Helal et al. 2012). Intervals of peritidal cycles dominated by dolomite are abundant in the areas of regional highs and on the inner platform during regressive periods, whereas limestone-rich cyclic intervals develop best near depocenters during transgression periods (Zhang et al. 2015). In the study area, this trend most likely resulted in the uneven distribution of the dolomite but was also related to sea-level fluctuations (Fig. 12). Of course, the dolomitizing fluids were easily partitioned by the regional highs, and the gently inclined, very shallow epicontinental carbonate platform also encourages vertical infiltration of the dolomitizing fluids while discouraging lateral migration, which may be the cause of the discontinuity in the dolomite distribution (as exemplified in wellD61 and well-D69). The bottom of the $\mathrm{Ma}_{5}^{5}$ submember 


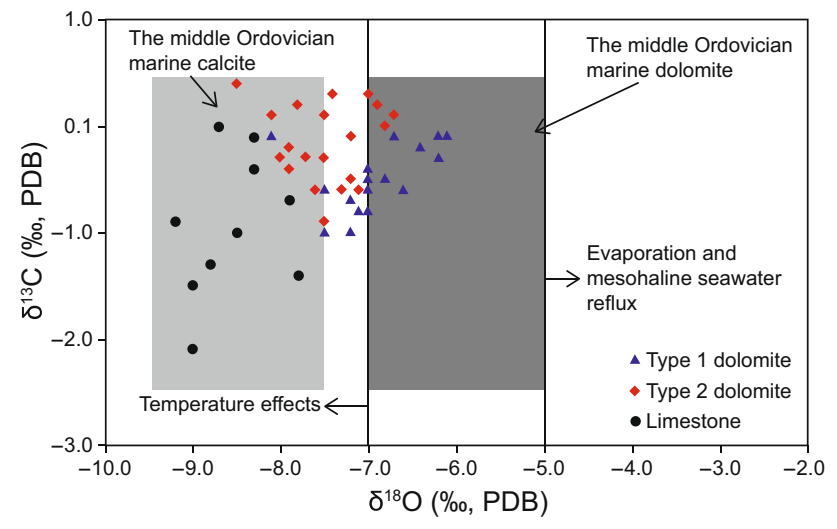

Fig. $7 \delta^{13} \mathrm{C}$ values versus $\delta^{18} \mathrm{O}$ values for the dolomites

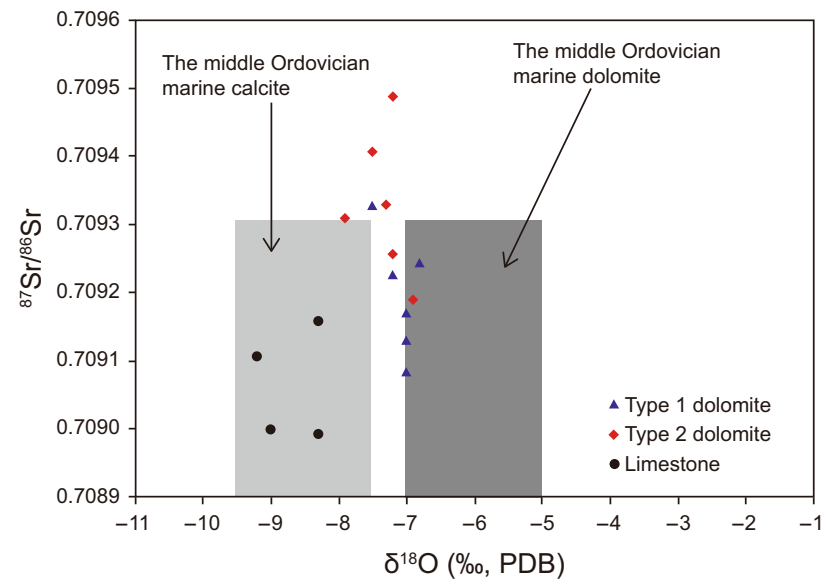

Fig. $8{ }^{87} \mathrm{Sr} /{ }^{86} \mathrm{Sr}$ ratios versus $\delta^{18} \mathrm{O}$ values for the dolomites

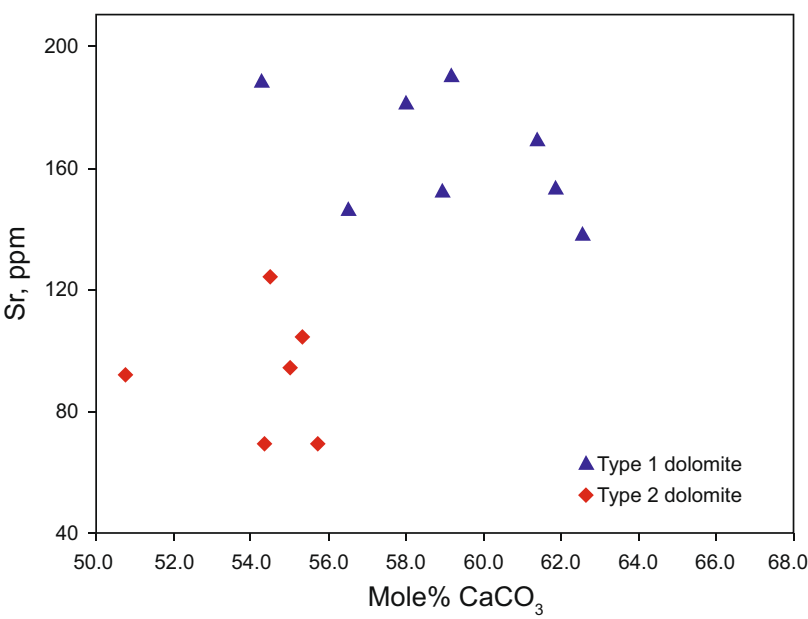

Fig. 9 Sr concentration versus $\mathrm{mol} \% \mathrm{CaCO}_{3}$ for the dolomites

contains a set of layered algal dolomites, which are an important indicator of the early genesis of the type 1 dolomite (Harwood and Sumner 2012). The relationship between the petrography and distribution of the dolomite is

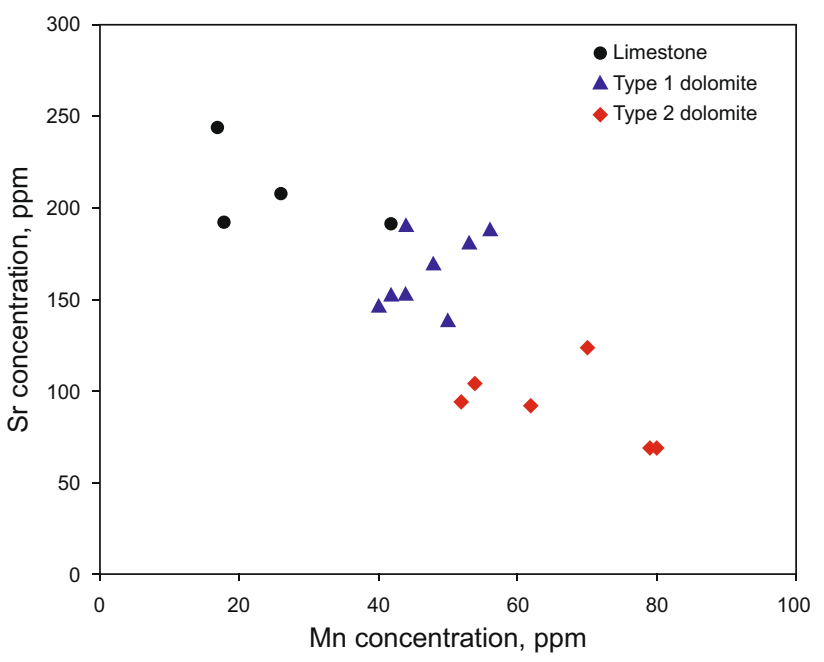

Fig. $10 \mathrm{Sr}$ versus $\mathrm{Mn}$ concentrations in the dolomites

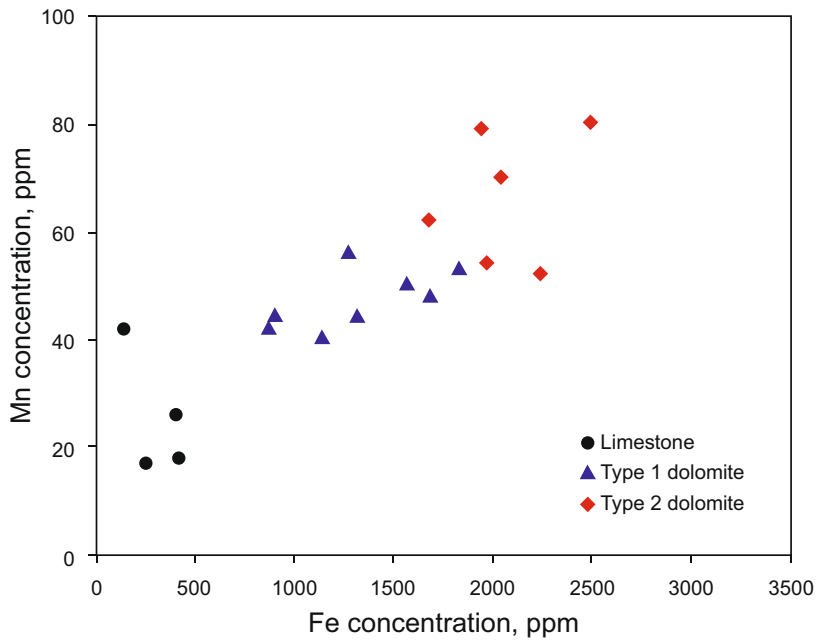

Fig. $11 \mathrm{Mn}$ versus $\mathrm{Fe}$ concentrations in the dolomites

illustrated by the fact that a few of the transgressive depositional facies contain stacks of partially dolomitized rocks and limestone cycles (Figs. 3, 4). This pattern indicates that the distribution of the syndepositional dolomite is closely associated with sea-level changes.

\subsection{Dolomitization mechanism}

The Middle Ordovician Ordos platform was protected from the open sea to the west by the central uplift and developed gentle slope $\left(<1^{\circ}\right)$, restricted evaporative tidal-flat facies in the $\mathrm{Ma}_{5}$ member of the Majiagou Formation (Zhou et al. 2011) (Fig. 12). The precipitation of anhydrite was conducive to elevated $\mathrm{Mg}^{2+} / \mathrm{Ca}^{2+}$ molar ratios and lowered the $\mathrm{SO}_{4}{ }^{2-}$ concentrations of the brines. Dolomitization was likely further promoted by low-sulfate concentrations due to sulfate reduction in the tidal-flat sediments (Shelton 
et al. 2009). Abundant pyrite has been shown to be syndepositional in tidal-flat sedimentary conditions and the meter-scale stratigraphy of the dolostone, which lacks massive gypsum/anhydrite, indicates that the synsedimentary deposits of the $\mathrm{Ma}_{5}^{5}$ submember developed in a very shallow and slightly altered seawater environment. Elevated salinity seawater percolated downward through the underlying carbonates, resulting in the dolomitization.

The rate of brine flux is proportional to the concentration of the brine and critically depends on the magnitude and distribution of the permeability (Jones et al. 2004). However, synsedimentary unconsolidated deposits generally have higher permeability and porosity, and the dolomitization may have occurred in extensive platformtop environments associated with the repeated flooding and reflux of marine water with slightly higher salinity.

The type 2 dolomite primarily consists of finely crystalline, regular crystal plane, euhedral to subhedral dolomite crystals that replaced the limestone matrix. The type 2 dolomite is closely associated with the type 1 dolomite in the stratigraphic column and is most likely related to the downward flow of modified seawater at elevated temperatures during burial (Figs. 3, 4) based on the following evidence. First, the type 2 dolomite is characterized by finely crystalline, regular crystal plane, euhedral to subhedral dolomite crystals that most likely predated or were coeval with early stylolitization at intermediate burial depths. Second, the bodies of the type 2 dolomite are scattered and discontinuous, vary greatly in thickness and generally decrease in abundance downward. The type 2 dolomites are characterized by the partial to complete replacement of muddy limestone/wackestone but rarely replace packstone that experienced early marine cementation (Fig. 5h), which resulted in a decrease in permeability. Thus, the replacement by dolomite likely postdates the calcite cementation. Finally, the type 2 dolomite displays lower $\delta^{18} \mathrm{O}$ values and $\mathrm{Sr}^{+}$concentrations and slightly higher $\mathrm{Na}^{+}, \mathrm{Fe}^{2+}$, and $\mathrm{Mn}^{2+}$ concentrations and ${ }^{87} \mathrm{Sr} /{ }^{86} \mathrm{Sr}$ ratios, suggesting that the type 2 dolomites precipitated from modified seawater and dolomitic fluids in the pore water and that their development was affected by elevated temperatures.
Thermal convection has been proposed by some researchers (Morrow 1998; Jones et al. 2004), but the type 2 dolomites are not likely related to thermal convection. The northern Ordos Basin may have experienced tectonism and large-scale heat flow anomalies during the Late Paleozoic (Wang et al. 2006), but thermal anomaly events are not consistent with the timing of the formation of the type 2 dolomites. Fault and fracture conduit systems are commonly important and efficient in delivering dolomitizing fluids to the overlying strata, thus causing extensive dolomitization (Qing and Mountjoy 1989). Faults are rare in the northern Ordos Basin, but fractures are well developed in the $\mathrm{Ma}_{5}^{5}$ submember, and parts of this unit have been affected by calcite cementation. However, the fractures are mostly present in the limestone, and the underlying fractured limestone displays no dolomitization features. Furthermore, the type 2 dolomite did not form from upward-migrating basinal fluids in a burial environment because the volume of the dolomite decreases downward.

\section{Conclusions}

The Middle Ordovician $\mathrm{Ma}_{5}^{5}$ submember carbonate unit in the northern Ordos Basin is partially to completely dolomitized. Two types of replacive dolomite are distinguished: (1) type 1 dolomite, which is primarily characterized by microcrystalline $(<30 \mu \mathrm{m})$, euhedral to subhedral dolomite crystals, mimetically replaces the precursor limestone, and is generally laminated and associated with gypsum-bearing microcrystalline dolomite; and (2) type 2 dolomite, which is present primarily as finely crystalline $(30-100 \mu \mathrm{m})$, regular crystal plane, euhedral to subhedral dolomite crystals that are truncated by stylolites, indicating that the type 2 dolomite most likely predated or developed simultaneously with the formation of the stylolites. Stratigraphic, petrographic, and geochemical data indicate that the type 1 dolomite formed in slightly evaporated Middle Ordovician seawater and that dolomitizing fluids may have been driven by density differences and elevation-related hydraulic head. The absence of

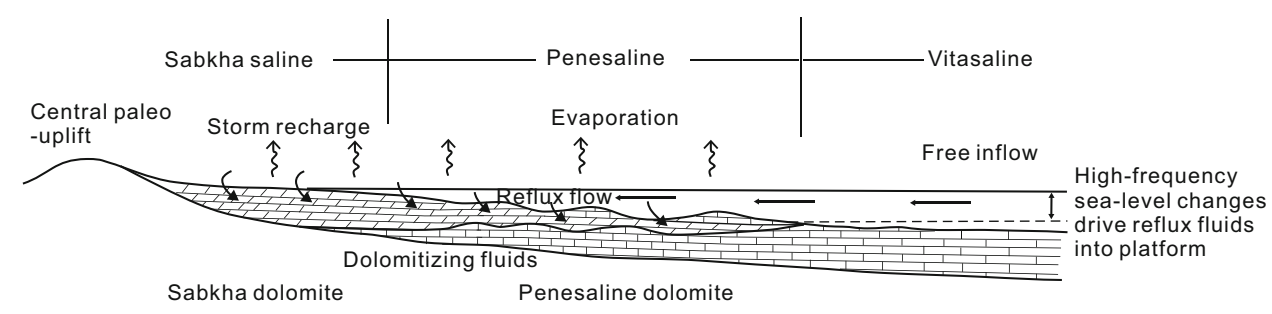

Fig. 12 Diagram indicating the dolomitization model of peritidal carbonates by slightly evaporated (penesaline) sea water in a restricted platform setting driven by high-frequency sea-level changes (after Adams and Rhodes 1960; Qing et al. 2001) 
depositional evaporites in the dolomitized intervals suggests that dolomitization was driven by the reflux of slightly evaporated seawater. The $\delta^{18} \mathrm{O}$ values of type 1 dolomite are slightly lower than those of the seawaterderived dolomite, suggesting that dolomite may have been recrystallized at higher temperatures during burial.

The type 2 dolomite has lower $\delta^{18} \mathrm{O}$ values and $\mathrm{Sr}^{+}$ concentrations and slightly higher $\mathrm{Na}^{+}, \mathrm{Fe}^{2+}$, and $\mathrm{Mn}^{2+}$ concentrations and ${ }^{87} \mathrm{Sr} /{ }^{86} \mathrm{Sr}$ ratios than the type 1 dolomite. These results suggest that the type 2 dolomites precipitated from modified brines and dolomitic fluids from pore water and that their development was affected by elevated temperatures. Their distribution and abundance are closely related to those of the type 1 dolomite, but their downward decrease in abundance and discontinuous lateral distribution suggest that the dolomitizing fluids were most likely related to the infiltration and diffusion of penesaline water that replaced the carbonate sediments in association with higher temperatures related to shallow burial. The relationship between the petrography and distribution of the dolomite is illustrated by the fact that a few of the transgressive depositional facies contain stacks of partially dolomitized rocks and limestone cycles, indicating that the distribution of the syndepositional dolomite is closely associated with cyclic sea-level changes, which may account for the development of the discrete dolomite bodies.

Acknowledgments This work was supported by the Major National Science and Technology Projects of China (Grant No. 2011ZX05045) and Sinopec (Grant No. 34550000-13-FW0403-0010). We thank Dr. Meng and Dr. Fu at the Isotope Laboratory of the State Key Laboratory of Oil and Gas Reservoir Geology and Exploitation, who checked the stable isotope analysis results.

Open Access This article is distributed under the terms of the Creative Commons Attribution 4.0 International License (http://crea tivecommons.org/licenses/by/4.0/), which permits unrestricted use, distribution, and reproduction in any medium, provided you give appropriate credit to the original author(s) and the source, provide a link to the Creative Commons license, and indicate if changes were made.

\section{References}

Adams JE, Rhodes ML. Dolomitization by seepage refluxion. AAPG Bull. 1960;44(12):1912-20.

Al-Helal AB, Whitaker FF, Xiao Y. Reactive transport modeling of brine reflux: dolomitization, anhydrite precipitation, and porosity evolution. J Sediment Res. 2012;82:196-215.

Banner JL. Application of the trace element and isotope geochemistry of strontium to studies of carbonate diagenesis. Sedimentology. 1995;42(5):805-24.

Banner JL, Hanson GN. Calculation of simultaneous isotope and trace element variations during water-rock interaction with applications to carbonate diagenesis. Geochim Cosmochim Acta. 1990;54(11):3123-37.
Davies GR, Smith LB. Structurally controlled hydrothermal dolomite reservoir facies: an overview. AAPG Bull. 2006;90(11): 1641-90.

Durocher S, Al-Aasm IS. Durocher S. Dolomitization and neomorphism of Mississippian (Visean) upper Debolt Formation, Blueberry field, northeastern British Columbia: geologic, petrologic, and chemical evidence. AAPG Bull. 1997;81(6):954-77.

Fabricius IL, Borre MK. Stylolites, porosity, depositional texture, and silicates in chalk facies sediments. Ontong Java Plateau-Gorm and Tyra fields, North Sea. Sedimentology. 2007;54(1):183-205.

Fang SX, Hou FH, Yang X, et al. Reservoirs pore space types and evolution in $\mathrm{M}_{5}^{5}$ to $\mathrm{M}_{5}^{1}$ sub-members of Majiagou Formation of Middle Ordovician in central gasfield area of Ordos Basin. Acta Pet Sin. 2009;25:2425-41 (in Chinese).

Feng ZZ, Bao ZD. Lithofacies paleogeography of Majiagou age of Ordovician in Ordos Basin. Acta Sedimentol Sin. 1999;17(1):1-8 (in Chinese).

Franzolin E, Merlini M, Poli S, et al. The temperature and compositional dependence of disordering in Fe-bearing dolomites. Am Miner. 2012;97:1676-84.

Friedman GM, Sun SQ. A reappraisal of dolomite abundance and occurrence in the Phanerozoic: discussion and reply. J Sediment Res. 1995;65(1a):244-6.

Fu JH, Wang BQ, Sun LY, et al. Dolomitization of Ordovician Majiagou Formation in Sulige region, Ordos Basin. Pet Geol Exp. 2011;33:268-73 (in Chinese).

Fu QL, Qing HR, Bergman K. Dolomitization of the Middle Devonian Winnipegosis carbonates in south-central Saskatchewan, Canada. Sedimentology. 2006;53(4):825-48.

Gregg JM, Bish DL, Kaczmarek SE, et al. Mineralogy, nucleation and growth of dolomite in the laboratory and sedimentary environment: a review. Sedimentology. 2015;62(6):1749-69.

Gregg JM, Shelton KL. Dolomitization and dolomite neomorphism in the back reef facies of the Bonneterre and Davis Formations (Cambrian), southeast Missouri. J Sediment Res. 1990;60(4):549-62.

Haeri-Ardakani O, Al-Aasm I, Coniglio M, et al. Diagenetic evolution and associated mineralization in Middle Devonian carbonates, southwestern Ontario, Canada. Bull Can Pet Geol. 2013;61(1):41-58.

Hardie LA. Dolomitization: a critical view of some current views. J Sediment Res. 1987;57:166-83.

Harwood CL, Sumner DY. Origins of microbial microstructures in the Neoproterozoic Beck Spring Dolomite: variations in microbial community and timing of lithification. J Sediment Res. 2012;82(9):709-22.

He XY, Shou JF, Shen AJ, et al. Geochemical characteristics and origin of dolomite: a case study from the middle assemblage of Ordovician Majiagou Formation Member 5 of the west of Jingbian Gas Field, Ordos Basin, North China. Pet Explor Dev. 2014;41(3):417-27.

Hu B, Kong FJ, Zhang YS, et al. The homogenization temperature in the fluid inclusions of Ordovician halite and paleoclimatic implication. Acta Geol Sin. 2014;88(S1):10-11.

Huang QY, Zhang SN, Ding XQ, et al. Origin of dolomite of Ordovician Majiagou Formation, western and southern margin of the Ordos Basin. Pet Geol Exp. 2010;32(2):146-7 (in Chinese).

Jones GD, Rostron BJ. Analysis of fluid flow constraints in regionalscale reflux dolomitization: constant versus variable-flux hydrogeological models. Bull Can Pet Geol. 2000;48(3):230-45.

Jones GD, Whitaker FF, Smart PL, et al. Numerical analysis of seawater circulation in carbonate platforms: II. The dynamic interaction between geothermal and brine reflux circulation. Am J Sci. 2004;304(3):250-84.

Lei BJ, Fu JH, Sun FJ, et al. Sequence stratigraphy of the Majiagou Formation, Ordos Basin: sedimentation and early diagenesis 
related to eustatic sea-level changes. J Stratigr. 2010;34(2):145-53 (in Chinese).

$\mathrm{Li} \mathrm{ZH}$, Zheng CB. Evoluation process of palaeokarst and influence to reservoir - a case for Ordovician of Ordos Basin. Nat Gas Geosci. 2004;15:247-52 (in Chinese).

Liu Y, Fu JH, Li JM. Dolomite genetic analysis on Ordovician Majiagou Formation in eastern Ordos Basin. J Oil Gas Technol. 2011;33:46-50 (in Chinese).

Loyd SJ, Corsetti FA. The origin of the millimeter-scale lamination in the Neoproterozoic lower Beck Spring Dolomite: implications for widespread, fine-scale, layer-parallel diagenesis in Precambrian carbonates. J Sediment Res. 2010;80:678-87.

Machel HG. Concepts and models of dolomitization: a critical reappraisal. Geol Soc Lond Spec Publ. 2004;235(1):7-63.

Mazzullo SJ. Geochemical and neomorphic alteration of dolomite: a review. Carbonates Evaporites. 1992;7(1):21-37.

McArthur JM, Howarth RJ, Bailey TR. Strontium isotope stratigraphy: LOWESS version 3: Best fit to the marine Sr-isotope curve for 0-590 Ma and accompanying look-up table for deriving numerical age. J Geol. 2001;109:155-70.

McKenzie J. Movement of subsurface waters under the sabkha Abu Dhabi, UAE, and its relation to evaporative dolomite genesis. Soc Econ Palaeontol Mineral. 1980;28:11-30.

Melim LA, Swart PK, Eberli GP. Mixing-zone diagenesis in the subsurface of Florida and the Bahamas. J Sediment Res. 2004;74(6):904-13.

Montañez IP, Read JF. Fluid-rock interaction history during stabilization of early dolomites, Upper Knox Group (Lower Ordovician), U.S. Appalachians. J Sediment Res. 1992;62(5):753-78.

Morrow DW. Regional subsurface dolomitization: models and constraints. Geosci Can. 1998;25(2):57-70.

Qing HR, Barnes CR, Buhl D, et al. The strontium isotopic composition of Ordovician and Silurian brachiopods and conodonts: relationships to geological events and implications for coeval seawater. Geochim Cosmochim Acta. 1998;62(10):1721-33.

Qing HR, Bosence DWJ, Rose EPF. Dolomitization by penesaline sea water in early Jurassic peritidal platform carbonates, Gibraltar, western Mediterranean. Sedimentology. 2001;48(1):153-63.

Qing HR, Mountjoy EW. Multistage dolomitization in Rainbow buildups, Middle Devonian Keg River Formation, Alberta, Canada. J Sediment Res. 1989;59(1):114-26.

Qing HR, Veizer J. Oxygen and carbon isotopic composition of Ordovician brachiopods: implications for coeval seawater. Geochim Cosmochim Acta. 1994;58(20):4429-42.

Read JF, Cangialosi M, Husinec A, et al. Coarse, fabric destructive post-depositional dolomites, Late Jurassic-Early Cretaceous Adriatic platform, Croatia: origin by mesohaline reflux. 2012 Geological Society of America Annual Meeting in Charlotte. 2012, 44: 456.

Rivers JM, Kyser TK, James NP. Salinity reflux and dolomitization of southern Australian slope sediments: the importance of low carbonate saturation levels. Sedimentology. 2012;59(2):445-65.

Rott CM, Qing HR. Early dolomitization and recrystallization in shallow marine carbonates, Mississippian Alida Beds, Williston Basin (Canada): evidence from petrography and isotope geochemistry. J Sediment Res. 2013;83(11):928-41.

Shelton KL, Gregg JM, Johnson AW. Replacement dolomites and ore sulfides as recorders of multiple fluids and fluid sources in the southeast Missouri Mississippi valley-type district: halogen ${ }^{87} \mathrm{Sr} /{ }^{86} \mathrm{Sr}{ }^{18} \mathrm{O}-{ }^{34} \mathrm{~S}$ systematics in the Bonneterre dolomite. Econ Geol. 2009;104(5):733-48.
Sibley DF. Unstable to stable transformations during dolomitization. J Geol. 1990;98:739-48.

Staudt WJ, Oswald EJ, Schoonen MAA. Determination of sodium, chloride and sulfate in dolomites: a new technique to constrain the composition of dolomitizing fluids. Chem Geol. 1993;107(s1-2):97-109.

Su ZT, Chen HD, Xu FY. Geochemistry and dolomitization mechanism of Majiagou dolomites in Ordovician, Ordos, China. Acta Pet Sin. 2011;27(8):2230-8 (in Chinese).

Swart PK. The geochemistry of carbonate diagenesis: the past, present and future. Sedimentology. 2015;62(5):1233-304.

Swart PK, Melim LA. The origin of dolomites in Tertiary sediments from the margin of Great Bahama Bank. J Sediment Res. 2000;70(3):738-48.

Veizer J, Ala D, Azmy K, et al. ${ }^{87} \mathrm{Sr} /{ }^{86} \mathrm{Sr}, \delta^{13} \mathrm{C}, \delta^{18} \mathrm{O}$ evolution of Phanerozoic seawater. Chem Geol. 1999;161(1):1586.

Wang BQ, Qiang ZT, Zhang F, et al. Isotope characteristics of dolomite from the fifth member of the Ordovician Majiagou Formation, the Ordos Basin. Geochimica. 2009;38(5):472-9 (in Chinese).

Wang DX, Wang AG, Zhang BG, et al. Geochemical characteristics of rare earth element of dolostones from Ma5 member of Majiagou Formation in Jingbian Gasfield, Ordos Basin: implications for the origin of diagenetic fluids. Nat Gas Geosci. 2015;26(4):641-9 (in Chinese).

Wang QF, Deng J, Yang LQ, et al. Tectonic constraints on the transformation of Paleozoic framework of uplift and depression in the Ordos Area. Acta Geol Sin. 2006;80(6):944-53.

Wang Z, Zhang Y, Zheng M, et al. Sr isotope geochemistry and depositional setting of carbonate in Ordovician, Ordos Basin, China. Acta Geol Sin. 2014;S1:262-4.

Warren J. Dolomite: occurrence, evolution and economically important associations. Earth Sci Rev. 2000;52(s 1-3):1-81.

Wheeler CW, Aharon P, Ferrell RE. Successions of late Cenozoic platform dolomites distinguished by texture, geochemistry, and crystal chemistry: Niue, South Pacific. J Sediment Res. 1989;69:239-55.

Yang $\mathrm{H}$, Bao H. Characteristics of hydrocarbon accumulation in the middle Ordovician assemblages and their significance for gas exploration in the Ordos Basin. Nat Gas Ind. 2011;31(12):11-20 (in Chinese).

Yang SZ, Jin WH, Li ZH. Multicycle superimposed basin form and evolution of Ordos Basin. Nat Gas Geosci. 2006;17:494-8 (in Chinese).

Zhang XF, Liu B, Cai ZX, et al. Dolomitization and carbonate reservoir formation. Geol Sci Technol Inf. 2010;29(3):79-85 (in Chinese).

Zhang YQ, Chen DZ, Zhou XQ, et al. Depositional facies and stratal cyclicity of dolomites in the lower Qiulitag Group (Upper Cambrian) in northwestern Tarim Basin, NW China. Facies. 2015;61(1):1-24 (in Chinese).

Zhao JX, Chen HD, Zhang JQ, et al. Genesis of dolomite in the fifth member of Majiagou Formation in the middle Ordos Basin. Acta Pet Sin. 2005;26:38-41 (in Chinese).

Zhao WZ, Shen AJ, Zheng JF, et al. The porosity origin of dolostone reservoirs in the Tarim, Sichuan and Ordos basins and its implication to reservoir prediction. Sci China Earth Sci. 2014;57(10):2498-511 (in Chinese).

Zhou JG, Zhang F, Guo QX, et al. Barrier-lagoon sedimentary model and reservoir distribution regularity of Lower-Ordovician Majiagou Formation in Ordos Basin. Acta Sedimentol Sin. 2011;29(1):64-71 (in Chinese). 